How things make things do things with words, or how to pay attention to what things have to say

\author{
Nicolas Bencherki \\ State University of New York at Albany \\ nbencherki@albany.edu \\ TÉLUQ Montréal \\ nicolas.bencherki@teluq.ca
}

\begin{abstract}
Published in Communication Research and Practice, at http://www.tandfonline.com/doi/abs/10.1080/22041451.2016.1214888
\end{abstract}

Limited free copies accessible at https://t.co/0oOd25CIO8

The first paragraph in this version is different from the published version to better reflect Luhamann's conception of communication.

Author note

I wish to thank the participants to the 2015 EGOS "Organization as Communication" special working group's sub-theme, as well as the guest editors and reviewers of this special issue, for their comments and suggestions. A special thanks to Bryanna Hebenstreit and James P. Snack for their insights and advice. 


\begin{abstract}
While organizational communication research has traditionally limited talk to human beings, a trend within the Montreal School (TMS) of the Communicational Constitution of Organizations (CCO) perspective acknowledges that 'things do things with words' as well, and criticizes the 'bifurcation of nature' into two distinct realms: materiality and discourse. Among others, this is what Cooren (2015) has suggested in the pages of this journal. However, due to a preference for studying human discourse, many TMS studies still may give the impression that only human spokespeople can make objects talk. This paper uses data from an ethnographic case study to argue that $\mathrm{CCO}$ is well equipped to recognize that other sorts of objects may speak as well, and that they enter the realm of language through yet other objects (i.e., their 'spokesthings'). In doing so, this paper advances an argument that will counter critiques of TMS scholarship that propose it reduces the role played by objects to their interpretation by humans.
\end{abstract}

Keywords: materiality, spokesthings, discourse, bifurcation of nature, organizational communication, $\mathrm{CCO}$ 


\section{How things make things do things with words: \\ or how to pay attention to what things have to say}

Research in organizational communication, and in particular studies concerning talk in organizational settings (Boden, 1994; Czarniawska-Joerges \& Joerges, 1988; ten Have, 1991) has for the most part considered the conversations of humans as its starting point. After all, talk regularly has been considered the privilege of human beings. For instance, in the Communicative Constitution of Organizations (CCO) tradition of organizational communication research, one of the three 'schools' (Schoeneborn et al., 2014), the Four Flows approach, questions whether nonnon-human agency and communication can be meaningful, thus locating meaning within the realm of humans only (McPhee \& Seibold, 1999). The Luhmannian trend of CCO, for its part, considers agency in terms of the self-reproducing power and agency of the communication process itself; a Luhmannian perspective therefore de-centers communication from either human or artefactual subjects (Blaschke, 2015; Schoeneborn, 2011). The third trend, the Montreal School, generally agrees with such a de-centering, but seeks to observe its materialization in the interactions of people and things. It is left alone attempting to explain the agency of "things" and, arguably, to deploy the material details of the communication processes referred to by the Luhmannian approach. ${ }^{1}$

Indeed, perspectives on (socio)materiality in organization studies have insisted - in various ways - that materiality and, in particular, technology play a part in the constitution of organizational reality (Leonardi, 2012). For the most part the perspectives that have been put forth recognize the role of artifacts, technologies and devices but maintain a distinction between the social and the material domains, as if they can be separated. That is the case of affordance

\footnotetext{
${ }^{1}$ This first paragraph has been altered from the published version to reflect conversations with Steffen Blaschke and Dennis Schoeneborn regarding Luhmann's conception of communication. I wish to thank them for their valuable suggestions.
} 
theory (Faraj \& Azad, 2012; Fayard \& Weeks, 2007), structuration theory (Orlikowski, 1992, 2007), situated action (Suchman, 1987), activity theory (Engeström, 2000; Engeström, Miettinen, \& Punamäki, 1999), or distributed cognition (Hutchins, 1995a, 1995b), amongst a long list of others. Putnam (2015) differentiates five different perspectives, all but one considers discourse and materiality as distinct phenomena. The exception is Orlikowski and Scott's perspective, which borrows from Barad's agential realism (2007). The literature, whatever its theoretical bent, continues to understand the involvement of objects and technology in action / agency / activity mostly through the spectrum of their use by human beings. Nardi (1996, p. 76), for instance, speaks of 'One's ability—and choice — to marshal and use resources'.

This article uses data from an ethnographic case study to argue that CCO is well-equipped to move us beyond this limited view of material agency and show that, not only can the objects humans use speak, but they enter the realm of language through yet other objects who speak for them (i.e., their 'spokesthings').

This paper starts by describing the Montreal School's CCO perspective on materiality in order to make the argument that this perspective provides the latitude to recognize that things make other things talk and, in so doing, move away from the view that things only participate in the world to the extent that we, humans, 'interpret' what they have to say. It then explores how things speaking for other things allow an 'objectivity' that is otherwise not possible, before presenting data from an ethnographic study to illustrate how this occurs in practice. It finishes by proposing a redefinition of objectivity and of the way things may gain access to language and participate in human sociality. 


\section{Materiality and The Montreal School Perspective}

The Montreal School (TMS) flavor of CCO (Brummans, 2006) has borrowed from ActorNetwork Theory the recognition that the distinction between, on the one hand, a social world made of speaking humans, and on the other, a material and natural realm made of mute objects, does not stand (Ashcraft, Kuhn, \& Cooren, 2009; Latour, 1993). Through the notions of textual agency (Brummans, 2007; Cooren, 2004, 2008) and the 'plenum of agencies' (Cooren, 2006), TMS researchers have acknowledged that things can do things with words (Cooren \& Bencherki, 2010).

To this day, however, the Montreal School has mostly limited its attention to cases where materiality is brought by humans into their conversations or writings. In this paper, I argue that this is an artifact of TMS's preferred methodological approach - the analysis of interactions, and conversations in particular. The TMS approach does, however, have the theoretical and empirical apparatus to recognize that things 'speak' in different ways, besides being mobilized in human talk. In fact, as I will show, from a TMS perspective there are cases when things' ability to speak on their own is crucial. For instance, we humans have delegated the job of making things talk to other things (i.e., phonation devices) like medical instruments and navigational devices.

Putnam (2015) classifies the 'plenum of agencies' perspective of TMS as giving privilege to the discourse side of the duality. I do not believe this is accurate, but I admit that the TMS literature has sometimes left misleading clues in that respect. For instance, Cooren and Taylor's (1997) argument for the constitutive power of communication focuses on the interplay between talk and text, with the result that the meaning of materiality appears to be solely constructed in human communication (Brummans, Cooren, \& Chaput, 2009). This confusion has also been fueled by the choice of cases. For instance, Vásquez, Schoeneborn and Sergi (2016) studied 
project proposal forms, a technical template and a presentation slide; Cooren's (2015) example of a museum-related creative project focused on a participant's oral presentation. These different studies discuss cases where verbal language is present, but what makes a difference in each case is the material (i.e., physical) availability of text or speech in given situations.

The apparent tension between a more conventional sense of materiality (i.e., physicality) and a more semiotic one may be traced back to contentious elements within TMS's underlying theory of materiality, namely actor-network theory (ANT). Indeed, while some ANT champions, such as Law (2009), embrace it as a 'material semiotics', the precise status of language and representation in the theory has been decried as ambiguous (c.f., Lenoir, 1994). Furthermore, some authors have called for greater acknowledgement of the non-discursive side of artifacts, in particular in the study of technology and its agency (Bardini, 2007).

In this paper I argue that when TMS scholars denounce the 'bifurcation of nature', (i.e., the separation of reality of things from their representation) they are not merely bringing the 'real' world into the realm of talk (c.f., Cooren, 2015). They are in fact rejecting the very terms of this alleged opposition. The distinction between the two realms simply does not hold, as illustrated in Arnaud, Mills, Legrand and Maton's (2016) study of the way texts, furniture, visual displays and geosocial arrangements - all material that can be read - translate an organization-wide strategy in the context of local branches, and allow resistance and negotiation between the branch and the senior managers driving the change. Such cases suggest we need to go past 'either/or' considerations and embrace the plurality of reality (Friedberg, 2000; Latour, 2000; Raffnsøe, Gudmand-Høyer, \& Thaning, 2014). I will therefore attempt to extend Cooren's (2015) proposal that things speak by using a more conventionally 'material' case to show how the very process by which things are brought into talk, or given the power to talk, is itself a material process. I 
will use the example of run-down buildings, which are both the object and the setting of the work of a tenants' association in a large North American city.

The argument that the process by which things are brought into talk is a material process in no way implies that humans do not play a part in the process. First of all, when things speak, they also speak to humans, who can then act (or not) on the basis of what they understand. Also, the tools through which things talk were designed by humans (e.g., engineers and designers) who embed particular scripts into them (Akrich, 1992). This is, for instance, what Groleau and Cooren (1999) describe in the account of a graphic design firm's use of computerized tools, which implement routines and procedures that otherwise would need to be learned and remembered by the workers. These include 'constative/performative' (p. 138) procedures, which may include tools that pick up specific aspects of reality as relevant and propose specific programs of action as appropriate.

My choice to focus on buildings and on the way they can tell about their condition, as opposed to managerial examples (such as the strategy case described by Arnaud et al., 2016), allows me to make my argument clearer by avoiding what some readers could view as a 'feedback loop' (i.e., humans reading tools that describe their own human activity). Of course, from the moment we are discussing human-made artifacts, we are, as Cooren (2015) rightly says, in the 'middle of things' or, to say it in another way, in a 'chain of agency' (2006) where humans and technology cannot be clearly distinguished. Even a building, in describing its own state of deterioration, is also saying something about the way its landlord or tenant have failed to care for it. The ability of speech is not limited to humans, nor do things only speak through humans, or about human activity. This is not at issue. What is less certain is the way things take part in the world they share with humans. Various typologies have been proposed for the relationship 
between things / technology / devices and the social / human / discursive (Leonardi, 2012;

Nicolini, Mengis, \& Swan, 2012; Orlikowski \& Scott, 2008; Putnam, 2015). Many of them, though, suppose a distinction between a 'technical subsystem' and a 'social subsystem' (Leonardi, 2012). The problem is to re-link the two - something that would take considerable theoretical effort. A more productive approach, perhaps, may be ANT's and TMS's suggestion to accept that our reality, in fact, is already hybrid (Latour, 1993, 2008). Then, speech is not the $a$ priori prerogative of humans. Whether someone or something can speak is an empirical matter. Being objective, rather than attempting to get interpretations 'right', then refers to paying attention to what objects have to say.

\section{The objectivity of 'spokesthings'}

The ethnographic field study that I analyze in this paper was chosen because of its concern with the issue of 'objectivity'. In the case of healthcare professionals this concern is tied to disciplinary standards, liability and ethics as well as with the practical issue of knowing what to do. For the workers of the tenants' association, that objectivity is instrumental and determines their ability to convince city official and courts to take measures to solve the housing problems that they document. While both sets of workers understand objectivity in the prosaic sense of 'fact-based' and different from personal judgement, it is interesting to note that this objectivity is achieved exactly by relying on objects.

In other words, objectivity consists of recognizing the fact that we share our sociability with things (I use the term 'objectivity' for convenience, even though, of course, if we reject the socio-material duality, it makes little sense). The social and material participate in the constitution of so many links between our ideas, judgements, etc., and the reality that we, humans, claim to be representing (Latour, 1988, 1996; Martine, Cooren, \& Bartels, 2015). 
Objectivity can therefore be said to be achieved when we, humans, can present ourselves as merely reporting what things are saying by themselves. The issue of objectivity, then, is figuring out 'how things do things with words' (Cooren \& Bencherki, 2010), but also how things can speak through yet other things that translate their 'objective' language into a verbal language that we, humans, can make sense of and that suggests a particular course of action for us to take. In fact, because I believe we humans need objects to speak without our direct help if we hope to ever achieve 'objectivity', I would like to argue for a somewhat radical perspective on the participation of things to the social - a perspective that recognizes things ability to 'talk'. Far from being esoteric, I propose that this ability rests on the many tools that we humans have devised to make such forms of talk possible - tools that I refer to as phonation devices (Latour, 2004; J. R. Taylor \& Van Every, 2000) and that act as 'spokesthings' for other non-humans. I prefer the word spokesthings rather than 'spokesartifacts' or 'spokesobjects' (Vásquez \& Cooren, 2011), to acknowledge fertility of the word 'things', which etymologically points to the idea of deliberation and meeting (Latour, 2005a). Things, interestingly, always already include talk. Beings, whether human or not, are in fact heterogeneous to begin with (Latour, 1993), and therefore any analytical language that researchers use to distinguish between them is necessarily provisional.

Indeed, the so-called 'material world' (Hardy \& Thomas, 2015) - an expression I actually reject, given that it precisely amounts to alluding to another world (the world of discourse and communication) that would be, in comparison, immaterial, which is not the case - regularly tells us about itself using verbal language but research so far has failed to acknowledge that form of participation. Yet, as will be made obvious by the case in this paper, without those tools that allow non-human things to talk, a large portion of what goes on in and around organizations can 
remain unaccounted for. After all, as French sociologist Gabriel Tarde (1893) recognized over a century ago, things are societies too (see also Cooren, 2010).

Recognizing that things make things talk allows moving away from a perspective where things would only participate in the world to the extent that we, humans, 'interpret' what they have to say. In fact, we have built those phonation devices, and regularly use them, exactly to avoid being accused of 'merely' interpreting what things have to say. Paradoxically, it is because we want unmediated access to the world that we add more mediators that help us gain such access (Latour, 2005b). Cooren and Matte's (2010) discussion of a measuring stick used by Doctors Without Borders workers to decide who, among African children, may get help from a nutrition centre, may be read as such an attempt from physicians to downplay their own interpretation of the kids' health situation, and to let the 'talking' be made by the stick.

This kind of argument will not appear new to those who are interested in the history of sciences or in sociotechnical controversies, in particular from a Science, Technology and Society (STS) perspective. Datson and Galison (1992), for instance, suggested that our current scientific obsession with objectivity has grown as we have developed technical means to 'visualize' data and to make facts speak for themselves. Borck (2008), for his part, has shown how the field of neurosciences has evolved along attempts to visualize the brain through various devices. Historical efforts at photographing ghosts may also be seen as technologically-mediated attempts to bring otherwise invisible reality into our social world (Gunning, 2008). More broadly, the way technology has allowed access to 'reality' has been the object of many STS studies (Baigrie, 1996; Bloor, 1991). While TMS scholars regularly draw on STS authors (in particular in the ANT tradition), the full extent of ANT's suggestion concerning the participation of objects in our common world has yet to be grasped in organizational communication. 
Recognizing that things make things do things with words will allow organizational communication research to acknowledge this participation, not only because objects are being mobilized in human conversations but also because they have technical means to access human language. To point this out, I will use a case that illustrates human actors' reliance on phonation devices (i.e., things that allow other things to talk). Indeed, I will show that the workers of a tenants' association use moisture meters, hygrometers, thermometers and, more prosaically, cameras to make the buildings in which they work 'say' things about their run-down condition, without relying on the workers' interpretation of the building's appearance. The ability of the buildings to speak on their own is crucial, as we will show, as the workers have to prove that the buildings are run down, i.e., that this judgment is not only their 'interpretation'.

The data were gathered through a participative ethnographic approach, throughout the sixteen years I was involved with that organization, including the last ten as a researcher. Given my personal involvement in the field, I consider my approach to be a mix of 'at-home' ethnography (Alvesson, 2009) and organizational autoethnography (Anderson, 2006; Anteby, 2013; Boyle \& Parry, 2007). Over that period, I visited buildings, helped prepare court cases for tenants, lodged complaints to city officials, and more generally became involved with the life of the organization. As part of various special projects, I have adopted an action research perspective (Brydon-Miller, Greenwood, \& Maguire, 2003) and helped the organization apply for grants, organize various events, and review its work methods. I amassed a vast assortment of interviews, videos, pictures, documents of all kinds, both specifically for research projects and as part of my involvement in the organization. In the preparation of this article, I have revisited some of the material I collected through the years, in particular three interviews explicitly 
addressing work tools, as well as many reports, pictures and my own notes and knowledge of the organization.

\section{How things may speak: Three perspectives}

Current theorizing on the way things may speak recognizes three perspectives that account for how they may speak. The first consists in describing things that are already textual or discursive in nature, such as documents, signs, slide presentations, etc. The second consists in considering communication as the circulation of action, beyond linguistic action. The third is the one I put forward here. It consists in observing the precise ways through which things enter the linguistic realm.

The first perspective has been undoubtedly the most popular in CCO literature, and is the one that underpins the notion of textual agency. This approach rests mainly on a reworked view of speech act theory (Austin, 1962; Searle, 1979). Cooren's (2004) example of a note reminding someone of a meeting, or Brummans' (2007) discussion of a euthanasia declaration both discuss documents with words written on them. The agency of the text, then, consists in its ability to transport those inscriptions so that they can be read, interpreted, debated, etc., again in another situation, somewhere else and at a different time.

In this perspective, things play a part beyond being mere surfaces for our human words. For instance, in their discussion of a blackboard on which a nurse inscribes vital signs of hospitalized children, Cooren and Bencherki (2010) show that the precise structure of the table he drew on the board and the prominence of the board in the room makes it easy for the nurse to see, at a glance, whether a child's condition is worsening or not. In other words, the blackboard becomes a computational device that turns singular inscriptions into a form of diagnosis, rather than a mere carrier of words and numbers. Groleau and Cooren (1999), for their part, show that 
computer software does not only convey signs and representations of work but also present the workflow (i.e., the program of action) in ways that guide workers through the production process.

A second approach to the way things may participate in communication consists in redefining the latter word - communication - as the circulation of action, beyond linguistic action. Communication then consists in allowing something to act at a distance, which may be done through linguistic inscription or translation (that's the first perspective above), but also otherwise. Theoretically, this perspective may be related to Latour's (1999a) notion of immutable mobiles (i.e., things than manage to remain 'the same' while moving around). They remain the same because, pragmatically, they keep producing the same effect, even though they in fact do so thanks to undergoing the changes necessary so that the effect is achieved in various situations.

Latour's example is that of a box with a matrix of cells in which soil samples from the Amazon are put, so that each cell represents a particular sampling site. This way, the reference between the soil and a particular geography is maintained, even though the soil sample is moved to a laboratory in France, thousands of miles away from the original site. A theoretical root of the second approach may be found in French philosopher Gilbert Simondon's (1958/2005) discussion of transduction, a notion through which he captures the fact that what circulates from one entity to the next is always action: through a push on a pedal, I communicate to my car my desire to move forward, and it is through further (mechanical or electric) action that this push is 'interpreted' and passed on to the engine and then to the wheels.

At no point does communication leave the firm ground of action. Simondon's originality consists in showing that even when we speak of 'messages' and 'signs', these are rooted in 
concrete action that circulates from kin to kin, from one being to the next (Bencherki, 2015a).

Closer to our concern here, Simondon recognizes that things not only communicate through language but researchers may want to take into account the variety of ways in which things contribute to our collective lives. TMS scholars have regularly been advocating for opening up analysis to those alternate modes of participation, whether as the establishment of relations of a relation between entities through intermediaries (Cooren, Bencherki, Chaput, \& Vásquez, 2015), as affect (Bencherki, 2015b) or otherwise. As Cooren (2000, p. 66) pointed out, 'a semiotician would have no problem with the proposition that two rooms communicate with each another [...] communication is the creation of a link between two entities.'

The third perspective is the one that I want to put forward here, and which in fact has been implicitly present in TMS literature. It consists in looking at the ways in which the non-linguistic communication of things can be translated into a language we humans may engage with. This perspective is consistent with ANT's insistence on the notion of translation (Callon, 1986; Latour, 2005b; Vásquez \& Cooren, 2011) where the term is taken both figuratively and literally. It may surprise researchers that things may speak, but in fact people make things speak as part of their daily work life, through their human language but also through further things, as shown in STS research, for instance. Engineers have created devices of all kinds to make things speak, and scientists in all sorts of fields have created standard tests and measurements to convert the ‘objective' symptoms of things into actionable language (Latour \& Woolgar, 1979).

This last perspective combines the first two: the devices we have invented turn the nonverbal 'language' of things of the second perspective into a language we, humans, can make sense of and which is the focus of the first perspective. People, as they carry out their work, are therefore routinely acknowledging that there are ways in which things speak to them. In fact, we 
humans have delegated the work of interpretation to yet other things. Many of the numbers that make a difference in our organizations (Fauré, Brummans, Giroux, \& Taylor, 2010; Quattrone, 2004) come from spokesthings that measure aspects of our organization's 'well-being' (e.g., sales, accounting ratios of all sorts, and employee leaves). Through those measurements, spokesthings make organizational reality available to us in a language that we understand and that helps us attend to our tasks.

The role of the taxi meter, for instance, may be understood to a large extent as replacing an improbable inter-subjectivity between the cab driver and the client regarding the distance travelled, by an 'objectivity', (i.e., by agreeing to delegate the decision concerning the total fare to an object). In a similar way, the time clock may be seen to establish an 'honest full day's work' (following the expression by F. W. Taylor, 1911) and resolve disputes over attendance. In this last view, discovering how things speak therefore amounts to empirically looking at the different things that translate what things have to say into language as we understand it.

No single perspective is better or truer than another. Each corresponds to different aspects of what it means to say that things do things and speak. All three combined acknowledge that things speak in a variety of ways, and that we engage with things in various ways. Here, however, I would like to focus on the fact that even what we believe to be a 'human' language may be mobilized by non-human agents, and that this possibility, in fact, rests on yet other things that we have invented to make this possible. As will be obvious from the case presented below, this is what makes 'objectivity' possible.

\section{The 'machines' of housing workers}

The Bigville Tenants' Association (a fictional name) was founded in the early 1970's by a group of Bigville University students who sought a means to fight for social justice. Bigville 
being a French-speaking city, all the data presented below is translated. While the organization has changed premises and personnel through time, it still offers the same three basic services: legal advice to tenants who show up at its walk-in clinic; an outreach program that consists of knocking on apartment doors to survey housing problems and convince tenants to address them; and the monitoring of government and city decisions that impact housing rights.

I became involved with the Bigville Tenants Association in 2000, first as an employee, then as a member of the Board of Directors, and finally, since 2007, as a researcher. My research approach, however, has always retained an aspect of advocacy through (a loose interpretation of) action research (Brydon-Miller et al., 2003; Chandler \& Torbert, 2003; Lewin, 1946). I have remained a volunteer, helped write grant applications, acted as an informal advisor, and continued to knock on doors occasionally. What I realized through all these years is that the organization was in a unique position, at the intersection of architectural, urban planning, social, and legal concerns.

The community workers had the very unique exigency of making a seemingly mute thing - an apartment building - say something about its condition, so they could figure out what course of action to follow and, in many cases, to translate the building's condition into a language comprehensible to judges and city inspectors. To do this, the community workers I observed used hygrometers to measure humidity in ambient air, moisture meters to measure humidity in walls, thermometers and regular digital cameras. As an older employee, Charles, reminded me, it is only in the past few years since I had left the organization that they acquired so many 'machines' and changed their work practices. It used to be that, except for heating issues for which they already had thermometers, other problems would simply be visually 
observed by community workers, who could then serve as witnesses to the tenants should the case end up in court.

In an interview, another employee, Tamara highlighted that even to this day providing witness to what she visually observes remains a big part of her work. That is because in spite of the availability of other tools the Rental Board, which is the trial court for housing issues, is not used to other forms of proof. However, this is insufficient as another colleague, Sylvia, told me on a different occasion. 'We can get into a building and it doesn't look like there are leaks.' However, that may be misleading, as 'there is mold, but the wall can look neat and clean, because the landlord painted over it.' This is particularly an issue because city inspectors, who do not have the same tools as the community workers, may give a notice to the landlord about a situation, but when they come back for a follow-up inspection the situation has been concealed. 'What does the landlord do? He puts plaster, he puts paint, and it lasts a while. [...] It's really just a visual inspection. [...] If he sees mold, he'll write it down, and if he doesn't, then it's as if the problem was resolved.'

During the same interview, Sylvia gave a particularly poignant example of why such a visual inspection is defective: she told me the story of an apartment where, 'in the bedroom, there is a big spot of mold, and it's so important that the whole family, there are five of them and they need to sleep in the living room, and they locked up that room, because they can't breathe.' Indeed, mold has been associated with respiratory diseases (see for example Kercsmar et al., 2006), and any person who has worked in run-down buildings will know the strong smell of severe mold. However, this experience is not enough. As Sylvia further explains, 'You know it, you can tell it's humid, and usually it smells of mold too, but... it [having the measurements] allows you to have another proof. [...] Usually, we already know.' 
Unfortunately an individual's experience-based testimony may not be sufficient to convince a city inspector or the courts that a building is unhealthy because its condition has been concealed. That is why, when Bigville Tenants' Association began collaborating with the public health physicians and scientists, who can issue (non-binding) recommendations regarding the healthiness of specific buildings, the community workers adopted some of the tools of their public health partners (in particular the moisture meters).

Since adopting these tools, community workers take measurements in each room, and then photograph the meter (either the moisture meter on the wall, the hygrometer, or the thermometer), to have proof of what the reading was on that day. With the moisture meter, they need to first indicate on the meter what type of surface the wall is and its composition, and then take multiple readings, as the presence of an electric cable or a metal part behind the wall may affect the reading. The strategy of taking photographs also explains why they prefer a basic moisture meter, which uses a needle that moves across a color spectrum (not unlike volume meter on old audio equipment), as opposed to the more sophisticated but less easy to read digital moisture meter (see Figure 1). As Sylvia explains, 'normally it stays in the green,' but as soon as the needle moves further towards the red zone, this indicates that there is a problem. When it hits the red, the meter also emits a screeching beep.

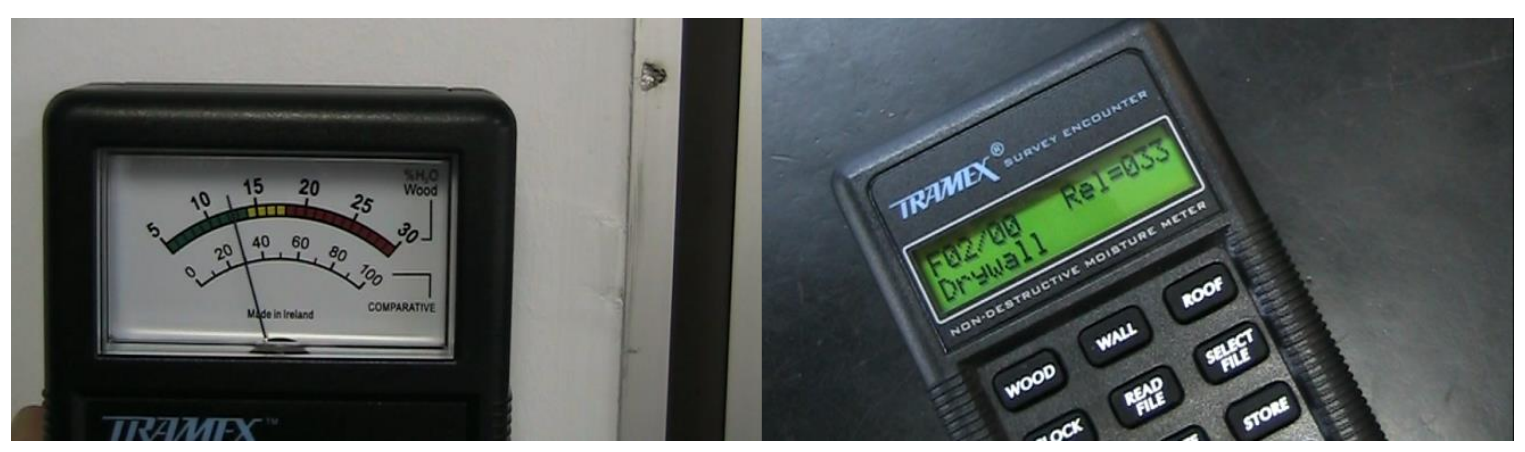

Figure 1 a \& b: The analog moisture meter besides its more sophisticated digital counterpart. 
Once back at the office, the workers organize the pictures into both computer and paper folders corresponding either to a tenant's case (if the person came to the walk-in clinic) or to a building (in the case of the outreach program), with an indication of the room and, for moisture meter photographs, of the wall section where the measure was made. When building a court case, as Charles showed me recently, he includes in the paper folder a plan of the apartment, where he uses numbered stars to reference printed photos. The photos, as shown in Figure 2, include a general overview, and then a zoom to the meter reading.

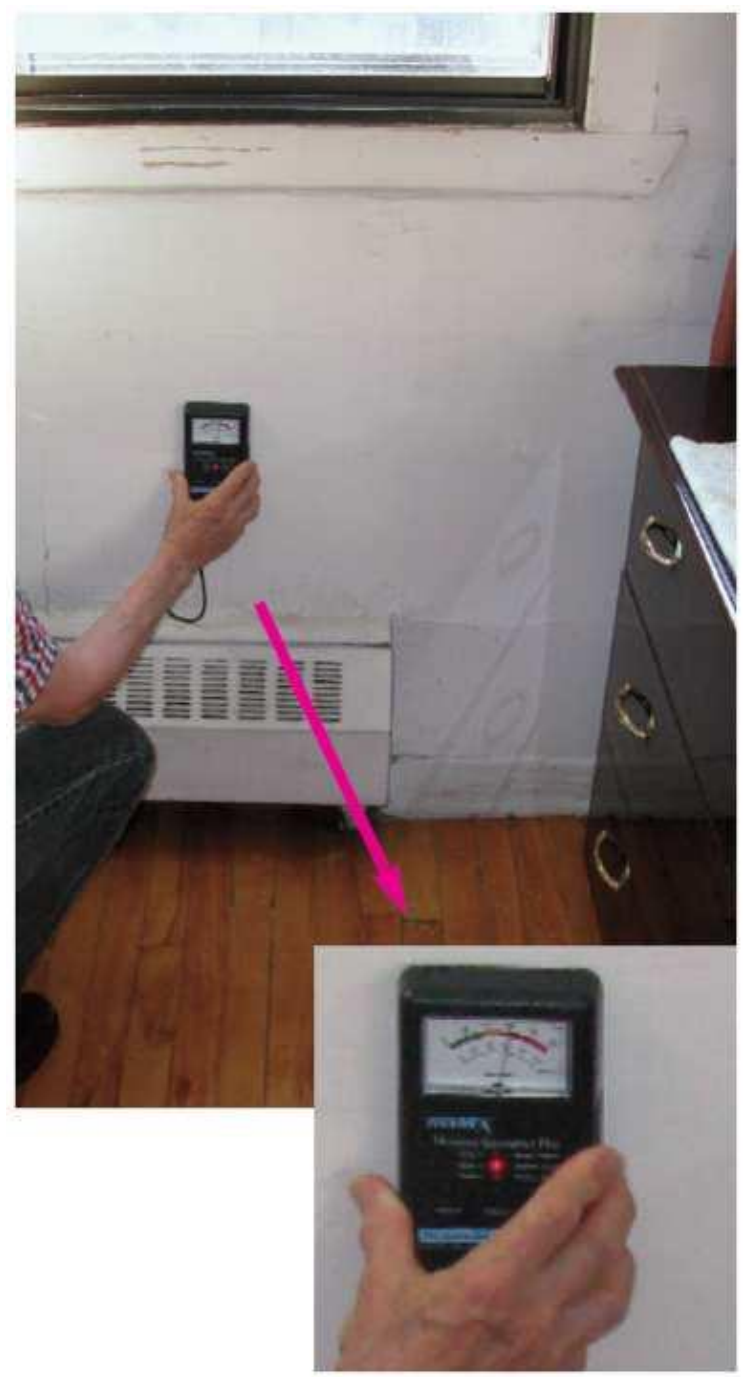

Figure 2: A picture of a moisture meter included in a report, along with a close-up on the meter reading. 
These documents are important in preparing court hearings. As Sylvia told me, 'if, say, the tenant gets to court and says "yeah, there's moisture in my room" and he's got nothing to prove it, he might as well just say anything [...] Everything you say in court has to be proven.' As I mentioned earlier, even readings from the community workers' meters are often not accepted as proof in court. A new strategy of the tenants' association is to request a report from the department of public health. Even though the tools they use are the same (remember that they are the ones who suggested them to the association), having a letter signed by a physician along with the rest of the evidence has greater weight than the pictures alone. Tamara explained, when I asked her about the way she built her proof, 'I don't know for the [court], but we can use that to convince the [public health administration] to visit the building.'

Besides convincing physicians and courts, an important challenge for the workers is to convince the tenants themselves there is a problem. Part of the community workers' job is to educate the district's tenants, many of whom are recent immigrants, regarding their rights and what constitutes acceptable housing conditions. This may be particularly important when some tenants require the organization's help to initiate class actions, where each tenant's signature counts. As Tamara explains, speaking of one particular person, 'the tenant didn't want to do anything about it but, when I showed him the moisture meter and the needle went "beep, beep" in the red, he understood and agreed.' Sylvia also told me about tenants who were more willing to undertake action, 'and who will do like "oh yeah!" [when they see the readings on the moisture meter] and that will motivate them.'

Their anecdotes point to the importance of getting the right kind of translations. As Charles mentioned to me, the newer, more sophisticated model of moisture meter that the 
organization acquired, while much more precise, produces more equivocal results. Indeed, the answer takes the form of a number on a black-and-green crystal liquid display or of a spreadsheet if the data is uploaded to a computer. The analog moisture meter, while simpler, produces more obvious results. Convincing tenants is simpler because their color code, as seen in Figure 1a, provides a direct interpretation of the results, clearly indicating whether or not there is a problem, whereas the measures of the digital meter need to be translated by another human, perhaps by comparison with a chart. The thermometer does not pose the same problem. This has in part to do with the fact that people, including judges and city inspectors, know that, say, 16 Celsius is cold for an apartment, but also because Bigville city regulations clearly require heating to be maintained at 21 Celsius. It is relatively uncontroversial when measures taken with a thermometer indicate any lower temperature. The landlord knows they must fix the main heating system or provide auxiliary heating. Similarly, if a picture shows a broken door, a wall full of mildew or an obvious water leakage then the fact that the picture referentially points to an actual, 'objective' instance is not contested.

\section{Discussion and conclusion}

The devices that workers use provide many ways in which the 'objective' reality of things or structures - here, buildings - is made to speak and to 'say' things about itself through numbers, scales and categories of all kinds. The ethnographic case presented in this paper illustrates the ways by which physical communication (heat exchange between the thermometer and the ambient air; the effect of humidity on the hygrometer and the moisture meter) are turned into conventional language (e.g., 21, 70\%, red...). These codes are meaningful to humans, and can be transcribed and carried around to a city inspector, added to a report for the public health administration or to a file to be presented in court, and made comparable against the law, city 
regulations and other verbal artifacts. The building can speak through the meters. The buildingwith-meter hybrid can speak (see Latour, 1999b) to humans, but also, through those humans, in yet another translation, to the institutional/organization reality with which they are dealing.

These translations, as they are enmeshed in further discourse, then suggest concrete programs of actions to the workers, to their colleagues or to their clients - 'this wall needs repairs' or 'this room needs to be properly heated'. When the phonation devices provide the right kind of translation, the opinion of community worker is not 'just' his or her opinion; rather, it is the numbers or categories of the tool, sometimes paired with the law or other institutional realities, that tells the worker what she or he should think and do. This is not only a matter of justification, but also a practical necessity in order to get the work done. Recognizing the work of 'spokesthings' implies that humans are not alone in doing the work of interpretation and in deciding what to do.

The perspective laid out here builds on Arnaud et al.'s (2016) idea that objects (i.e., physical) operate as translations. In their case, the translation was from broader organizational strategy to local situations. They showed that the layout of an office, compartments where paperwork was sorted, as well as tables and documents that embody procedures, made concretely present, but also more concretely negotiable, a nation-wide organizational strategy at the local office level. What I add to their work is that, besides strategy or other facets of the organization, things also translate other physical things and make them relevant to people's work. Indeed, just as space and objects allow people to better engage with a seemingly abstract strategy or one that does not align with preferred ways of working, a similar translation is needed to engage with buildings that may appear merely physical and irrelevant to human activity. While objects have been mostly theorized as either the supports of human language, the objects of human 
conversations, or as exercising physical constraint on human activity, the fact empirically illustrated by the Bigville Tenants' Association case is that we humans create tools to listen to them and to translate what they have to say into a language we understand, and thus multiply the ways in which they participate in our actions. This has been hinted at in the extant organizational communication literature (Cooren \& Matte, 2010), but has not yet been systematically discussed. The organizational communication literature needs to further acknowledge that things - whether seemingly abstract such as strategy or more concrete such as buildings - speak in a variety of ways, including by having their own way of communicating (the second way things may speak that I evoked earlier). Only when this occurs can we fully recognize the ways in which humans have been helping things enter the realm of human language, making them relevant to us (and commensurate to our laws, practices, etc.) and allowing them to let us know what they indicate or dictate. In fact, we have been creating tools to allow them to do these things.

A critique on the perspective proposed here could be that what I call 'spokesthings' are nothing but texts in the sense of textual agency. Of course, a hygrometer is also a set of humanmade algorithms - but it is also much more. It is precisely because a human engineer made it, integrating into it some algorithm connecting all sorts of components, that it can, in its turn, connect the three perspectives described earlier. The hygrometer shows us numbers that humans can understand (first perspective), that translate a physical mode of communication (second perspective), and that therefore provide objects with the ability to 'speak' (third perspective). All three perspectives are better understood as empirically intertwined, even though I insisted here on the third.

As for TMS authors insisting on examining cases that are more specifically about text and talk, even such obviously 'linguistic' examples are not merely reminding us about what we 
agreed on earlier, or carrying out decisions to a different place and time. They are telling us what some other non-human is saying by converting a non-human action into a form of human language. My contribution, by taking the more obviously physical example of a building, insists, along with Arnaud, Mills, Legrand and Maton (2016), that TMS scholars have not simply brought things into the realm of discourse, but that they have actually rejected the bifurcation - a bifurcation that people, in their everyday work, routinely reject.

I also propose that understanding that objects may speak is particularly important in order to appreciate how objectivity is practically reached. Recognizing the work of spokesthings makes it obvious that objects, in fact, have means to take part in our deliberations and disputes, and to provide their own perspective. This leads to a redefinition of 'objectivity' as the participation of objects in our conversations about reality (Latour, 1996; see also Martine et al., 2015). This is not to say that objectivity is not a 'construction', but this sociality includes objects whose voice must be heard. For instance, Hutchins (1995a) has shown how the objective achievement of the positioning of a warship on the waters, prior to the existence of a GPS, involved a work of translating landmarks and other physical objects into coordinates, thanks to visors, maps, rulers and a variety of tools. The work of interpretation was shared among all of these participants, in what Hutchins called 'distributed cognition'. As long as there is, on the one hand, a material and natural realm, and on the other a bunch of humans attempting to understand it (Latour, 1993), then truth and objectivity are, in the words of American philosopher Richard Rorty (cited in Misak, 2013, p. 230), 'merely labels for what our peers will let us get away with saying'. 


\section{References}

Akrich, M. (1992). The De-scription of Technical Objects. In W. E. Bijker \& J. Law (Eds.), Shaping Technology/Building Society (pp. 205-224). Cambridge, MA: MIT Press.

Alvesson, M. (2009). At-home Ethnography: Struggling with Closeness and Closure. In S. Ybema, D. Yanow, H. Wels, \& F. H. Kamsteeg (Eds.), Organizational Ethnography: Studying the Complexity of Everyday Life (pp. 156-174). London: Sage.

Anderson, L. (2006). Analytic Autoethnography. Journal of Contemporary Ethnography, 35(4), 373-395.

Anteby, M. (2013). Relaxing the Taboo on Telling Our Own Stories: Upholding Professional Distance and Personal Involvement. Organization Science, 24(4), 1277-1290. http://doi.org/10.1287/orsc.1120.0777

Arnaud, N., Mills, C. E., Legrand, C., \& Maton, E. (2016). Materializing Strategy in Mundane Tools: the Key to Coupling Global Strategy and Local Strategy Practice?: Materializing Strategy in Mundane Tools. British Journal of Management, 27(1), 38-57. http://doi.org/10.1111/1467-8551.12144

Ashcraft, K. L., Kuhn, T. R., \& Cooren, F. (2009). Constitutional Amendments: "Materializing” Organizational Communication. The Academy of Management Annals, 3(1), 1-64. http://doi.org/10.1080/19416520903047186

Austin, J. L. (1962). How to Do Things with Words. Cambridge, MA: Harvard Univ. Press.

Baigrie, B. S. (Ed.). (1996). Picturing Knowledge: Historical and Philosophical Problems Concerning the Use of Art in Science. Toronto: University of Toronto Press. 
Barad, K. (2007). Meeting the Universe Halfway: Quantum Physics and the Entanglement of Matter and Meaning. Durham, NC: Duke University Press.

Bardini, T. (2007). Retour sur une (d)ébauche : Une problématique communicationnelle du changement technique. tic\&société, (Vol. 1, n¹). http://doi.org/10.4000/ticetsociete.245

Bencherki, N. (2015a). Organizational Constitution of Communication: How a CCO-specific Theory of Communication Could be Conceived, and How Gilbert Simondon May Help. Presented at the 65th International Communication Association Annual Conference, San Juan, Puerto Rico.

Bencherki, N. (2015b). Pour une communication organisationnelle affective : une perspective préindividuelle de l'action et de la constitution des organisations. Communiquer. Revue de communication sociale et publique, (15), 123-139. http://doi.org/10.4000/communiquer.1701

Bloor, D. (1991). Knowledge and Social Imagery (2nd ed.). University of Chicago Press.

Boden, D. (1994). The business of talk: organizations in action. Cambridge: Polity Press.

Borck, C. (2008). Recording the brain at work: the visible, the readable, and the invisible in electroencephalography. Journal of the History of the Neurosciences, 17(3), 367-379. http://doi.org/10.1080/09647040701348332

Boyle, M., \& Parry, K. (2007). Telling the Whole Story: The Case for Organizational Autoethnography. Culture and Organization, 13(3), 185-190. http://doi.org/10.1080/14759550701486480

Brummans, B. H. J. M. (2006). The Montréal School and the question of agency. In F. Cooren, J. R. Taylor, \& E. J. Van Every (Eds.), Communication as organizing: Empirical and 
theoretical explorations in the dynamic of text and conversation (pp. 197-211). Mahwah, NJ: Lawrence-Erlbaum.

Brummans, B. H. J. M. (2007). Death by document: Tracing the agency of a text. Qualitative Inquiry, 13(5), 711-727.

Brummans, B. H. J. M., Cooren, F., \& Chaput, M. (2009). Discourse, communication and organisational ontology. In F. Bargiela-Chiappini (Ed.), The Handbook of Business Discourse (pp. 53-65). Edinburgh, UK: Edinburgh University Press.

Brydon-Miller, M., Greenwood, D., \& Maguire, P. (2003). Why Action Research? Action Research, 1(1), 9-28. http://doi.org/10.1177/14767503030011002

Callon, M. (1986). Some elements of a sociology of translation: domestication of the scallops and the fishermen of St Brieuc Bay. In J. Law (Ed.), Power, action and belief: a new sociology of knowledge? (pp. 196-223). London: Routledge.

Castor, T., \& Cooren, F. (2006). Organizations as Hybrid forms of Life: The Implications of the Selection of Agency in Problem Formulation. Management Communication Quarterly, 19(4), 570-600. http://doi.org/10.1177/0893318905284764

Chandler, D., \& Torbert, B. (2003). Transforming Inquiry and Action Interweaving 27 Flavors of Action Research. Action Research, 1(2), 133-152.

http://doi.org/10.1177/14767503030012002

Cooren, F. (2000). The organizing property of communication. Amsterdam/Philadelphia: J. Benjamins.

Cooren, F. (2004). Textual agency: How texts do things in organizational settings. Organization, 11(373-393). 
Cooren, F. (2006). The organizational world as a plenum of agencies. In F. Cooren, J. R. Taylor, \& E. J. Van Every (Eds.), Communication as organizing: Practical approaches to research into the dynamic of text and conversation (pp. 81-100). Mahwah, NJ: Lawrence Erlbaum.

Cooren, F. (2008). Between semiotics and pragmatics: Opening language studies to textual agency. Journal of Pragmatics, 40(1), 1-16. http://doi.org/10.1016/j.pragma.2006.11.018

Cooren, F. (2010). Action and Agency in Dialogue: Passion, Ventriloquism and Incarnation. Amsterdam/Philadelphia: John Benjamins.

Cooren, F. (2015). In medias res: communication, existence, and materiality. Communication Research and Practice, 1-15. http://doi.org/10.1080/22041451.2015.1110075

Cooren, F., \& Bencherki, N. (2010). How Things Do Things With Words: Ventriloquism, Passion and Technology. Encyclopaideia, Journal of Phenomenology and Education, (28), 35-61.

Cooren, F., Bencherki, N., Chaput, M., \& Vásquez, C. (2015). The Communicative Constitution of Strategy-Making: Exploring Fleeting Moments of Strategy. In D. Golsorkhi, L. Rouleau, D. Seidl, \& E. Vaara (Eds.), The Cambridge Handbook of Strategy as Practice (pp. 370-393). Cambridge: Cambridge University Press.

Cooren, F., \& Matte, F. (2010). For a constitutive pragmatics: Obama, Médecins Sans Frontières and the measuring stick. Pragmatics and Society, 1(1), 9-31. http://doi.org/10.1075/ps.1.1.02coo 
Cooren, F., \& Taylor, J. R. (1997). Organization as an Effect of Mediation: Redefining the Link Between Organization and Communication. Communication Theory, 7(3), 219-260. http://doi.org/10.1111/j.1468-2885.1997.tb00151.x

Czarniawska-Joerges, B., \& Joerges, B. (1988). How to Control Things with Words: Organizational Talk and Control. Management Communication Quarterly, 2(2), 170-193. http://doi.org/10.1177/0893318988002002003

Daston, L., \& Galison, P. (1992). The Image of Objectivity. Representations, (40), 81-128. http://doi.org/10.2307/2928741

Engeström, Y. (2000). Activity theory as a framework for analyzing and redesigning work. Ergnomics, 43(7), 960-974.

Engeström, Y., Miettinen, R., \& Punamäki, R.-L. (Eds.). (1999). Perspectives on Activity Theory. Cambridge: Cambridge University Press.

Faraj, S., \& Azad, B. (2012). The materiality of technology: An affordance perspective. In P. M. Leonardi, B. A. Nardi, \& J. Kallinikos (Eds.), Materiality and Organizing: Social Interaction in a Technological World (pp. 237-258). Oxford: Oxford University Press.

Fauré, B., Brummans, B. H. J. M., Giroux, H., \& Taylor, J. R. (2010). The calculation of business, or the business of calculation? Accounting as organizing through everyday communication. Human Relations, 63(8), 1249-1273. http://doi.org/10.1177/0018726709355658

Fayard, A.-L., \& Weeks, J. (2007). Photocopiers and Water-coolers: The Affordances of Informal Interaction. Organization Studies, 28(5), 605-634. http://doi.org/10.1177/0170840606068310 
Friedberg, E. (2000). Going Beyond the Either/Or. Journal of Management and Governance, 4(1), 35-52. http://doi.org/10.1023/a:1009977815841

Groleau, C., \& Cooren, F. (1999). A socio-semiotic approach to computerization: Bridging the gap between ethnographers and systems analysts. The Communication Review, 3(1-2), 125-164. http://doi.org/10.1080/10714429909368576

Gunning, T. (2008). Invisible Worlds, Visible Media. In C. Keller (Ed.), Brought to Light: Photography and the Invisible, 1840-1900 (pp. 51-63). New Haven, CT: Yale University Press.

Hardy, C., \& Thomas, R. (2015). Discourse in a Material World. Journal of Management Studies, n/a-n/a. http://doi.org/10.1111/joms.12113

Hutchins, E. (1995a). Cognition in the wild. Cambridge, Mass.: MIT Press.

Hutchins, E. (1995b). How a Cockpit Remembers Its Speeds. Cognitive Science, 19(3), 265-288. http://doi.org/10.1207/s15516709cog1903_1

Kercsmar, C. M., Dearborn, D. G., Schluchter, M., Xue, L., Kirchner, H. L., Sobolewski, J., ... Allan, T. (2006). Reduction in Asthma Morbidity in Children as a Result of Home Remediation Aimed at Moisture Sources. Environmental Health Perspectives, 114(10), 1574-1580. http://doi.org/10.2307/3838183

Latour, B. (1988). A Relativistic Account of Einstein's Relativity. Social Studies of Science, $18(1), 3-44$.

Latour, B. (1993). We have never been modern. Cambridge, MA: Harvard University Press.

Latour, B. (1996). On Interobjectivity. Mind, Culture, and Activity, 3(4), 228-245. http://doi.org/10.1207/s15327884mca0304_2 
Latour, B. (1999a). Circulating Reference: Sampling the Soil in the Amazon Forest. In Pandora's Hope: Essays on the Reality of Science Studies. Cambridge, MA: Harvard University Press.

Latour, B. (1999b). Pandora's hope : essays on the reality of science studies. Cambridge, Mass.: Harvard University Press.

Latour, B. (2000). On the Partial Existence of Existing and Nonexisting Objects. In L. Daston (Ed.), Biographies of Scientific Objects (pp. 247-269). Chicago, IL: University Of Chicago Press.

Latour, B. (2004). Politics of nature : how to bring the sciences into democracy. Cambridge, Mass.: Harvard University Press.

Latour, B. (2005a). From Realpolitik to Dingpolitik: or How to Make Things Public. In B. Latour \& P. Weibel (Eds.), Making Things Public: Atmospheres of Democracy (pp. 1441). Cambridge, MA: MIT Press.

Latour, B. (2005b). Reassembling the social : an introduction to actor-network-theory. Oxford; New York: Oxford University Press.

Latour, B. (2008). What is the Style of Matters of Concern? Assen, The Netherlands: Royal Van Gorcum.

Latour, B., \& Woolgar, S. (1979). Laboratory life : the social construction of scientific facts. Beverly Hills: Sage Publications.

Law, J. (2009). Actor network theory and material semiotics. The New Blackwell Companion to Social Theory, 3, 141-158. 
Lenoir, T. (1994). Was the Last Turn The Right Turn? The Semiotic Turn and A. J. Greimas. Configurations, 2(1), 119-136.

Leonardi, P. M. (2012). Materiality, Sociomateriality, and Socio-Technical Systems: What Do These Terms Mean? How are They Related? Do We Need Them? In P. M. Leonardi, B. A. Nardi, \& J. Kallinikos (Eds.), Materiality and Organizing: Social Interaction in a Technological World (pp. 25-48). Oxford: Oxford University Press. Retrieved from http://papers.ssrn.com/abstract=2129878

Lewin, K. (1946). Action research and minority problems. Journal of Social Issues, 2(4), 34-46.

Martine, T., Cooren, F., \& Bartels, G. (2015). Assessing Creativity Through its Degrees of Objectivity: An Actor-Network Approach to Creativity. Presented at the 65th International Communication Association Annual Conference, San Juan, Puerto Rico.

McPhee, R. D., \& Seibold, D. R. (1999). Responses to the Finalist Essays. Management Communication Quarterly, 13(2), 327-336. http://doi.org/10.1177/0893318999132009

Misak, C. J. (2013). The American Pragmatists. Oxford: Oxford University Press.

Nardi, B. A. (1996). Studying context: A comparison of activity theory, situated action models, and distributed cognition. In Context and consciousness: Activity theory and humancomputer interaction (pp. 69-102). Cambridge, MA: MIT Press. Retrieved from http://books.google.com/books?hl=en\&lr=\&id=JeqcgP1S2UAC\&oi=fnd\&pg=PA69\&dq= info:LOyVGvJ7PHEJ:scholar.google.com\&ots=e_gaVztUCp\&sig=aK_UwafKBksTJZk mesOr53AzZ3g 
Nicolini, D., Mengis, J., \& Swan, J. (2012). Understanding the Role of Objects in CrossDisciplinary Collaboration. Organization Science, 23(3), 612-629. http://doi.org/10.1287/orsc.1110.0664

Orlikowski, W. J. (1992). The Duality of Technology: Rethinking the Concept of Technology in Organizations. Organization Theory, 3(3), 398-427.

Orlikowski, W. J. (2007). Sociomaterial Practices: Exploring Technology at Work. Organization Studies, 28(9), 1435-1448. http://doi.org/10.1177/0170840607081138

Orlikowski, W. J., \& Scott, S. V. (2008). Sociomateriality: Challenging the Separation of Technology, Work and Organization. The Academy of Management Annals, 2(1), 433474. http://doi.org/10.1080/19416520802211644

Putnam, L. L. (2015). Unpacking the Dialectic: Alternative Views on the Discourse-Materiality Relationship. Journal of Management Studies, 52(5), 706-716. http://doi.org/10.1111/joms.12115

Quattrone, P. (2004). Accounting for God: accounting and accountability practices in the Society of Jesus (Italy, XVI-XVII centuries). Accounting, Organizations and Society, 29(7), 647-683. http://doi.org/10.1016/j.aos.2004.03.001

Raffnsøe, S., Gudmand-Høyer, M., \& Thaning, M. S. (2014). Foucault's dispositive: The perspicacity of dispositive analytics in organizational research. Organization, 1350508414549885 .

Schoeneborn, D. (2011). Organization as Communication: A Luhmannian Perspective. Management Communication Quarterly, 25(4), 663-689. http://doi.org/10.1177/0893318911405622 
Schoeneborn, D., Blaschke, S., Cooren, F., McPhee, R. D., Seidl, D., \& Taylor, J. R. (2014). The Three Schools of CCO Thinking: Interactive Dialogue and Systematic Comparison. Management Communication Quarterly, 28(2), 285-316. http://doi.org/10.1177/0893318914527000

Searle, J. R. (1979). Expression and meaning : studies in the theory of speech acts. Cambridge, Eng. ; New York: Cambridge University Press.

Simondon, G. (2005). L'individuation à la lumière des notions de forme et d'information. Grenoble: Jérôme Millon. (Original work published 1958)

Suchman, L. (1987). Plans and situated action: the problem of human-machine interaction. Cambridge: Cambridge University Press.

Tarde, G. (1893). Monadologie et sociologie. (J.-M. Tremblay, Ed.). Chicoutimi, QC: J.-M. Tremblay.

Taylor, F. W. (1911). The Principles of Scientific Management. Retrieved from http://www.gutenberg.org/etext/6435

Taylor, J. R., \& Van Every, E. J. (2000). The emergent organization : communication as its site and surface. Mahwah, N.J.: Lawrence Erlbaum Associates.

ten Have, P. (1991). Talk and institution: A reconsideration of the "asymmetry" of doctor-patient interaction. In D. H. Zimmerman \& D. Boden (Eds.), Talk and social structure: Studies in ethnomethodology and conversation analysis (pp. 138-163). Berkeley, CA: University of California Press. 
Vásquez, C., \& Cooren, F. (2011). Passion in action: An analysis of translation and treason. In P. Quattrone, C. McLean, F. Puyou, \& N. Thrift (Eds.), Imagining organizations: Performative imagery in business and beyond (pp. 191-212). London: Routledge.

Vásquez, C., Schoeneborn, D., \& Sergi, V. (2016). Summoning the spirits: Organizational texts and the (dis)ordering properties of communication. Human Relations, 69(3), 629-659. http://doi.org/10.1177/0018726715589422 